\title{
O PRINCÍPIO DA PROIBIÇÃO DO RETROCESSO E SUA APLICAÇÃO AOS DIREITOS CIVIS E POLÍTICOS NO ÂMBITO DO ESTADO DEMOCRÁTICO DE DIREITO.
}

\section{THE PRINCIPLE OF KICKING PROHIBITION AND TO THEIR APPLICATION IN CIVIL AND POLITICAL RIGHTS IN THE DEMOCRATIC STATE.}

\author{
${ }^{1}$ Daniel Brocanelli Garabini
}

\section{RESUMO}

$\mathrm{O}$ artigo pretende investigar a incidência do princípio da proibição do retrocesso em relação aos direitos civis e políticos no Estado Democrático de Direito. Verifica-se sua origem no princípio democrático e na concepção universal e indivisível dos Direitos humanos. A responsabilidade internacional do Estado decorrente da adesão aos tratados de direitos humanos impõe o exercício do controle de convencionalidade tendo como referência o aludido princípio. A metodologia buscará analisar as três dimensões da dogmática jurídica, analítica, empírica e normativa, definindo os conceitos jurídicos citados. O problema e a hipótese serão abordados com fundamento na Teoria dos Direitos Fundamentais.

Palavras-chave: Responsabilidade, Convencionalidade, Princípios, Direitos humanos, Estado democrático de direito

\begin{abstract}
The article intends to investigate the incidence of the principle of kicking prohibition with respect to civil and political rights in a democratic state. There is a rise in the democratic principle and the universal and indivisible conception of human rights. The responsibility of the State arising from the accession to human rights treaties require the exercise of control of conventionality with reference to the aforementioned principle. The methodology will seek to analyze the three dimensions of legal dogmatic. The problem and the hypothesis will be addressed on the basis of Theory of Fundamental Rights.
\end{abstract}

Keywords: Responsibility, Conventionality, Principles, Human rights, Democratic state

\footnotetext{
${ }^{1}$ Mestrando em Mestrado em Direito pela Fundação Universidade de Itaúna - FUIT, Minas Gerais (Brasil). Defensor Público do Estado de Minas Gerais - DPMG, Minas Gerais (Brasil). E-mail: dbgbhdef@gmail.com
} 


\section{INTRODUÇÃO}

O desenvolvimento econômico e tecnológico no mundo contemporâneo atua, de forma decisiva, para um mundo globalizado. Como consequência desse fenômeno, cria-se e amplia-se direitos e deveres correlatos, aumentando os desafios na busca da efetivação dos direitos e do cumprimento dos deveres assumidos pelos Estados, perante a sociedade internacional.

Desde a Revolução Francesa e a Declaração Universal dos Direitos do Homem e do Cidadão, passando pela Carta das Nações Unidas, que propôs a autolimitação da soberania com o objetivo de proteger os Direitos Humanos, constata-se a crescente pressão política para a defesa e efetivação desses direitos.

Nesse compasso, os Direitos Humanos são todos os direitos da pessoa consagrados internacionalmente pelos sistemas de proteção, constituindo-se em um padrão de proteção mínimo, cabendo aos Estados ir além do já disposto, de modo que a normatização internacional seja gradativamente suplementar e coadjuvante.

Por outro lado, havendo desrespeito aos direitos humanos, o acesso à justiça deve ser visto não só como direito fundamental, mas concebido em seu caráter universal e, neste ponto, a importância do tema ganha destaque nas palavras de Mauro Cappelletti:

$\mathrm{O}$ acesso à justiça pode, portanto, ser encarado como o requisito fundamental - o mais básico dos direitos humanos - de um sistema jurídico moderno e igualitário que pretenda garantir, e não apenas proclamar, os direitos de $\operatorname{todos}^{1}$ (CAPPELLETTI,1988)

As consequências jurídicas das violações das obrigações convencionais de proteção dos Direitos Humanos requerem uma análise aprofundada, sendo "o dever de reparação uma obrigação nova e adicional, que se soma à obrigação primária (de respeito aos direitos humanos) cuja violação constitui o ato ilícito internacional"2 (CANÇADO TRINDADE, 1999).

A partir da constatação da responsabilidade do Estado e do exercício do controle de convencionalidade pelos órgãos competentes, seria possível invocar o princípio da proibição do retrocesso em relação aos direitos civis e políticos?

\footnotetext{
${ }^{1}$ CAPPELlETTI, Mauro. Acesso à justiça. Tradução de Ellen Gracie Northfleet. Porto Alegre, Fabris, 1988, p. 12.

${ }^{2}$ CANÇADO TRINDADE, Antônio Augusto. Tratado de Direito Internacional dos Direitos Humanos, volume II, Porto Alegre, Sérgio Antônio Fabris Editor, 1999, p. 171.
} 
A opção metodológica escolhida será o método hipotético-dedutivo, buscando analisar as três dimensões da dogmática jurídica: analítica (dissecção sistemático - conceitual do direito vigente, visando clareza conceitual, ausência de contradição e coerência); a empírica que diz respeito a cognição do direito positivo válido nas leis além dos precedentes judiciais e, por fim, a normativa, que busca, a partir do direito positivo válido, determinar qual a decisão correta em um caso concreto. (processo construtivo - norma de decisão).

A hipótese de que a proibição do retrocesso incide sobre direitos civis e políticos terá como suporte a concepção dos Direitos Humanos no Estado Democrático de Direito e a Teoria dos Direitos Fundamentais.

De início, tratar-se-á do tema da responsabilidade internacional do Estado frente ao descumprimento de Tratados de Direitos Humanos e o controle de convencionalidade exercido pelo sistema interamericano de proteção dos Direitos Humanos e no âmbito interno do Estado brasileiro.

Após, analisar-se-á o fenômeno jurídico da internalização dos Tratados de Direitos Humanos no ordenamento jurídico brasileiro, destacando-se a tese da supralegalidade adotada pela Supremo Tribunal Federal e o controle jurisdicional (difuso) de convencionalidade das Leis, e sua importância para efetivação dos direitos consagrados na Convenção Americana de Direitos Humanos.

Em última análise, será proposta a contextualização do princípio da vedação do retrocesso no âmbito do Estado Democrático de Direito, buscando a sua máxima efetivação notadamente em relação aos direitos civis e políticos fundamentais.

\section{A RESPONSABILIDADE INTERNACIONAL DOS ESTADOS POR DESCUMPRIMENTO DE TRATADOS DE DIREITOS HUMANOS}

O Estado foi concebido como entidade política centralizada a partir das monarquias absolutistas, sendo influenciado pelo movimento liberal e pelo ideal de Constituição, que regularia a organização do poder e garantiria os direitos fundamentais do indivíduo.

Surge nesse período histórico o Estado Liberal de Direito sob o primado da lei, por meio de revoluções que romperam com as estruturas políticas da época (revolução francesa, inglesa, independência dos treze estados americanos). ${ }^{3}$

\footnotetext{
${ }^{3}$ O Estado de Direito Liberal, erigido sob o influxo da ideologia liberal burguesa, apresentava dois núcleos constitutivos: o primeiro voltado para proclamar a primazia do indivíduo sujeitos de direitos naturais e
} 
A noção de soberania dos Estados Nacionais consolidou-se como qualidade intrínseca ao poder estatal. Em que pesem os avanços experimentados em relação à proteção dos direitos humanos e a autolimitação gradual da soberania, a responsabilidade internacional por atos ilícitos ainda não se desvencilhou do dogmatismo inerente a essas concepções jusfilosóficas.

Hodiernamente, a responsabilidade internacional do Estado difere em dois aspectos: a responsabilidade entre Estados, decorrentes da prática de ato ilícito que gera um dano a outro Estado, e a responsabilidade estatal no que diz respeito ao descumprimento dos Tratados de Direitos Humanos. Neste ínterim, adverte Valério Mazzuoli

A responsabilidade internacional do Estado é o instituto jurídico que visa responsabilizar determinado Estado pela prática de um ato atentatório (ilícito) ao Direito Internacional perpetrado contra os direitos ou a dignidade de outro Estado, prevendo certa reparação a este último pelos prejuízos e gravames que injustamente sofreu. Este conceito leva em conta apenas os Estados nas suas relações entre si. É evidente que nas relações do Estado com as pessoas sujeitas à sua jurisdição o instituto da responsabilidade internacional também opera, notadamente no que diz respeito às violações estatais de direitos humanos.

Historicamente, os Estados eram concebidos como únicos atores internacionais que compunham a sociedade internacional. A partir da necessidade urgente de se resguardar os direitos mais básicos do ser humano, notadamente a partir das guerras do século XX, passa-se a entender o indivíduo como sujeitos de direitos e deveres no cenário internacional, como parte inerente da personalidade jurídica de cada pessoa ${ }^{5}$.

Dessa forma, a responsabilidade do Estado se torna mais ampla, acarretando sanções aos Estados infratores, notadamente em matéria de direitos humanos, seja por um ato do Poder Executivo, Legislativo ou Judiciário.

Evidencia-se que a legitimidade ad causam para provocar os órgãos internacionais incumbidos de velar pela observância dos Tratados internacionais de Direitos Humanos inclui o cidadão, diferentemente do que ocorre em eventual descumprimento de obrigações convencionais de outra natureza.

inalienáveis, inerentes à dignidade da pessoa; e o segundo, decorrente do primeiro, a rigorosa limitação do poder político através de técnicas especiais a fim de garantir o exercício dos direitos individuais (TOMAZ, Carlos Alberto Simões de. Direito, Razão e Sensibilidade (construindo um modelo de juiz para a proteção dos direitos fundamentais). Pará de Minas, MG: Virtual books Editora, 2014, p. 15).

${ }^{4}$ MAZZUOLI, Valerio de Oliveira. Curso de direito internacional público. 5. ed. rev., atual. e ampl. -São Paulo: Editora Revista dos Tribunais, 2011, p. 557.

${ }^{5}$ Vide: LIMA, Renata Mantovani de. Tribunais híbridos e justiça internacional penal. Belo Horizonte: Arraes Editores, 2012, p. 77. 
A doutrina mais aprimorada adverte que o sistema de proteção dos Direitos Humanos tem suas peculiaridades, e deve primar pelo princípio pro homine e a sociedade internacional, em conjunto com os Estados, devem velar pelos princípios do pactum sunt servanda e da boafé diante das obrigações assumidas. Sendo assim, o indivíduo é parte legítima para levar o seu caso aos sistemas de proteção dos Direitos Humanos, uma vez lesado o seu direito, desde que respeitadas as regulamentações da $\mathrm{CADH}$ para abertura do procedimento próprio.

Isto porque os Tratados de Direitos Humanos "prescrevem obrigações de caráter essencialmente objetivo, a serem garantidas ou implementadas coletivamente, e enfatizam a predominância de considerações de interesse geral ou ordre public, que transcendem os interesses individuais das Partes contratantes"6.

Em complemento, é evidente a necessidade de se implementar instrumentos democráticos de participação diante do descumprimento das obrigações relativas aos direitos humanos, conforme magistério de Flávia Piovesan:

\footnotetext{
"os indivíduos convertem-se em sujeitos de Direito Internacional - tradicionalmente, uma arena em que só os Estados podiam participar. (...) É correto afirmar, no entanto, que ainda se faz necessário democratizar determinados instrumentos e instituições internacionais de modo que possam prover um espaço participativo mais eficaz, que permita maior atuação de indivíduos e de entidades não governamentais mediante legitimação ampliada nos procedimentos e instâncias internacionais" 7
}

Além do sistema de proteção interamericano de direitos humanos, que engloba as Américas do Norte e do Sul, conta-se atualmente com mais dois sistemas de proteção, a saber, o Europeu e o Africano, todos eles desenvolvendo importante trabalho na efetivação dos direitos e garantias previstos nos diversos Tratados de Direitos humanos.

No sistema americano, do qual o Brasil faz parte, o arcabouço normativo mínimo de proteção abarca a Carta da Organização dos Estados Americanos (OEA) e a Declaração Americana dos Direitos Humanos, ambos convencionados no ano de 1948, além do pacto de São José de Costa Rica, que trata dos direitos civis e políticos e do protocolo de São Salvador, regulamentando os direitos sociais, econômicos e culturais.

\footnotetext{
${ }^{6}$ CANÇADO TRINDADE, Antônio Augusto. Tratado de Direito Internacional dos Direitos Humanos, volume II, Porto Alegre, Sérgio Antônio Fabris Editor, 1999, p. 29.

${ }^{7}$ PIOVESAN, Flávia. Direitos Humanos e o direito constitucional internacional. 12 ed.rev. atual.São Paulo: Saraiva, 2011, p. 414.
} 


\section{A INTERNALIZAÇÃO DOS TRATADOS DE DIREITOS HUMANOS NO ORDENAMENTO JURÍDICO BRASILEIRO E $O$ CONTROLE DE CONVENCIONALIDADE DAS LEIS}

O Direito Internacional se faz presente em todas as áreas de nossas vidas, não só nas relações entre Estados, sobretudo nas relações cotidianas do cidadão comum. Sobre essa questão, a Sociedade Americana de Direito publicou, no ano de 2006, um documento intitulado: Direito Internacional - 100 maneiras como ele influencia nossas vidas - e que nos leva a refletir e a compreender a importância das normas internacionais no mundo pós- moderno. ${ }^{8}$

Para além das relações civis, comerciais, trabalhistas e de cooperação tecnológica e científica, o Direito Internacional tem sido essencial no que diz respeito à proteção dos Direitos Humanos.

Uma vez constatado o dever de reparar o dano atribuível a um determinado Estado, torna-se necessário analisar o fenômeno da internalização dos Tratados internacionais no ordenamento jurídico do Brasil, identificando o controle de convencionalidade posto em evidência nos Tribunais pátrios.

\subsection{A internalização dos Tratados e Convenções no ordenamento jurídico brasileiro e a tese da supralegalidade}

Após as duas Guerras Mundiais do século XX, a sociedade internacional se voltou para os problemas relacionados com a dignidade da pessoa humana de forma incisiva.

A partir daí concentrou-se esforços no sentido de se estabelecer um rol de direitos mínimos que assegurariam a coexistência dos povos de maneira harmônica, "na construção de uma normatividade internacional eficaz, a fim de resguardar e proteger esses direitos, até então inexistente ". 9

No Brasil, após alguns avanços e retrocessos, foi promulgada a Constituição da República de 1988, que traz em seu texto expressivas conquistas em relação à proteção e garantia dos direitos fundamentais.

\footnotetext{
${ }^{8}$ Direitos fundamentais e sua proteção nos planos Interno e Internacional / Aziz Tuffi Saliba, Luiz Manoel Gomes Júnior e Gregório Assagra deAlmeida; Belo Horizonte: Arraes Editores, 2010, p. 174.

9 MAZZUOLI, Valerio de Oliveira. Curso de direito internacional público. 5. ed. rev., atual. e ampl. -São Paulo: Editora Revista dos Tribunais, 2011, p. 813.
} 
O marco decisivo para mudanças de paradigmas até então adotados repousaria na norma do artigo $5^{\circ}, \S 2^{\circ}$, ao estabelecer que "os direitos e garantias expressos nesta Constituição não excluem outros decorrentes do regime e dos princípios por ela adotados, ou dos tratados internacionais em que a República Federativa do Brasil seja parte"10

Trata-se do que comumente se denominou pela doutrina mais abalizada como cláusula aberta de recepção ${ }^{11}$, o que afetou em grande medida as concepções jurídicas tradicionais, colocando em discussão dogmas até então "sacralizados", a exemplo do conceito de Estado, de soberania, de território, de Constituição como instrumento de fechamento do sistema jurídico interno.

Contudo, a promulgação da Emenda Constitucional 45/04 incorporou ao texto constitucional o parágrafo terceiro ao artigo quinto ${ }^{12}$, de caráter restritivo, exigindo a aprovação qualificada para que tratados internacionais de direitos humanos possam ser considerados como normas constitucionais, tal como ocorreu com a aprovação da Convenção sobre os direitos da pessoa com deficiência, sendo esta considerada materialmente e formalmente constitucional.

A par dessa discussão, a tese prevalente é a de que os Tratados de Direitos Humanos ingressam no ordenamento jurídico como normas supralegais, conforme entendimento esposado pelo Supremo Tribunal Federal no RE 466.343/SP e no HC 87.585/TO ${ }^{13}$ no ano de 2008, desde que não aprovados pelo quórum qualificado exigido para as emendas constitucionais.

Vale dizer que as normas convencionais de Direitos Humanos estão em uma disposição hierárquica acima das leis e abaixo da Constituição, não sendo integrantes do bloco de constitucionalidade para efeito de controle concentrado realizado pelo STF. Os demais tratados internacionais, uma vez internalizados na ordem jurídica, adquirem o "status" de leis ordinárias.

10 BRASIL. Constituição (1988). Constituição da República Federativa do Brasil. Disponível em:〈http:www.senado.gov.br/sicon>. Acesso em: 03.05.2015.

${ }^{11}$ No Brasil, defendem esta tese Antônio Augusto Cançado Trindade e Flávia Piovesan, os quais entendem que os $\S 1^{\circ}$ e $2^{\circ}$ do artigo $5^{\circ}$ da Constituição caracterizar-se-iam, respectivamente, como garantes da aplicabilidade direta e do caráter constitucional dos tratados de direitos humanos dos quais o Brasil é signatário (MENDES, Gilmar Ferreira. Curso de Direito Constitucional / Gilmar Ferreira Mendes, Inocêncio Mártires Coelho, Paulo Gustavo Gonet Branco. 2 ed. rev. e atual. São Paulo: Saraiva, 2008, p. 694).

${ }^{12} \S 3^{\circ}$ Os tratados e convenções internacionais sobre direitos humanos que forem aprovados, em cada Casa do Congresso Nacional, em dois turnos, por três quintos dos votos dos respectivos membros, serão equivalentes às emendas constitucionais (BRASIL. Constituição (1988). Constituição da República Federativa do Brasil. Disponível em:〈http:www.senado.gov.br/sicon>. Acesso em: 03.05.2015).

${ }^{13}$ Disponível em:<http:www.stf.jus.br/>. Acesso em: 03.05.2015. 
É imprescindível que os Tratados de Direitos Humanos sejam concebidos como referenciais hermenêuticos para a interpretação das disposições constitucionais, postura que já vem sendo adotada pelo Supremo Tribunal Federal em sua jurisprudência, conforme acentua Antônio Moreira Maués ${ }^{14}$ :

A análise da decisão do caso do depositário infiel evidencia que, apesar das diferenças entre a tese da constitucionalidade e a da supralegalidade, ambas as hipóteses abrem a possibilidade de que a Constituição - e não apenas as leis infraconstitucionais - seja interpretada de maneira compatível com os tratados internacionais de direitos humanos. Seria essa decisão um caso isolado? O exame da jurisprudência do Tribunal mostra que, mesmo antes de 2008, já começava a se manifestar uma nova orientação que conferia maior força normativa aos tratados internacionais de direitos humanos. A partir da adoção da tese da supralegalidade, verificamos que esses precedentes se consolidam e novos precedentes são estabelecidos, utilizando os tratados de direitos humanos, especialmente a CADH, para interpretar a Constituição, tal como veremos nos casos abaixo:

a) segundo o artigo 7.2 da CADH: "Ninguém pode ser privado de sua liberdade física, salvo pelas causas e nas condições previamente fixadas pelas constituições políticas dos Estados Partes ou pelas leis de acordo com elas promulgadas".

Esse dispositivo tem sido utilizado pelo STF na interpretação do princípio da presunção de inocência (art. $5^{\circ}$, LVII) em casos que envolvem o direito do condenado a recorrer em liberdade. No $\mathrm{HC} \mathrm{n}^{\circ} 99.891$ (J. 15/09/2009), o STF concedeu a ordem contra decisão do STJ que havia mantido a execução da pena após atendido o duplo grau de jurisdição. Ratificando que o Tribunal não reconhece a possibilidade constitucional de execução provisória da pena, tendo em vista a presunção de inocência, o alcance desta é estabelecido nos contornos da $\mathrm{CADH}$, para reconhecer que ela não assegura ao condenado o direito de sempre recorrer em liberdade, uma vez que cabe a cada sistema jurídico estabelecer, por lei, os casos de prisão cautelar. No direito brasileiro, isso implica o reconhecimento da excepcionalidade da prisão cautelar, que deve atender aos requisitos do artigo 312 do Código de Processo Penal e às razões justificadoras de sua absoluta necessidade.

Os Tratados de Direitos Humanos devem ser postos em evidência ao se interpretar qualquer dispositivo constitucional ou infraconstitucional, servindo com bússola para o intérprete da lei, visto que esses diplomas normativos visam ao interesse maior de proteção dos direitos inerentes à condição humana.

Neste prisma, Antônio Augusto Cançado Trindade ensina que "a natureza especial dos tratados de direitos humanos tem incidência, como não poderia deixar de ser, em seu processo de interpretação"(CANÇADO TRINDADE,1999), com vistas na máxima efetivação dos direitos fundamentais do ser humano.

\footnotetext{
${ }^{14}$ MAUÉS, Antônio Moreira. Supralegalidade dos Tratados internacionais de Direitos Humanos e interpretação constitucional SUR - REVISTA INTERNACIONAL DE DIREITOS HUMANOS. 18 SUR 215-235 (2013), p. 220.
} 


\title{
2.2 O Controle de Convencionalidade das Leis
}

O controle difuso de convencionalidade das leis é o instrumento de verificação de compatibilidade entre a norma infraconstitucional e os Tratados Internacionais que integram determinado ordenamento jurídico. Essa verificação de compatibilidade é realizada pelos Juízes ou órgãos colegiados dos Tribunais de Justiça espalhados pelo país.

No Brasil, tomando-se como paradigma o posicionamento do Supremo Tribunal Federal adotando a tese da supralegalidade, os Tratados de Direitos Humanos servem como limite vertical para a produção normativa interna, cabendo aos Juízes e Tribunais do país declararem inválidas normas infraconstitucionais que violam esses Tratados.

Valério de Oliveira Mazzuoli aduz que:

\begin{abstract}
A compatibilidade do direito doméstico com os tratados internacionais de direitos humanos em vigor no país faz-se por meio do controle de convencionalidade, que é complementar e coadjuvante (jamais subsidiário) do conhecido controle de constitucionalidade.

A expressão "controle de convencionalidade" ainda é pouco conhecida no Brasil, não tendo sido objeto de qualquer estudo entre nós até o presente momento. O controle de convencionalidade tem por finalidade compatibilizar verticalmente as normas domésticas (as espécies de leis, lato sensu, vigentes no país) com os tratados internacionais de direitos humanos ratificados pelo Estado e em vigor no território nacional.
\end{abstract}

A tese supracitada tem gerado constantes debates na doutrina e jurisprudência pátrias, podendo-se citar como exemplo recente de controle difuso de convencionalidade no Brasil a implantação das chamadas "audiências de custódia".

O artigo 7.5 da Convenção Americana de Direitos Humanos (também denominada de Pacto de São José da Costa Rica), dispõe: “Toda pessoa presa, detida ou retida deve ser conduzida, sem demora, à presença de um juiz ou outra autoridade autorizada por lei a exercer funções judiciais".

Em que pesem esses Tratados estarem em vigor no Brasil desde 1992, o preso ou detido não era apresentado à autoridade judicial, sendo vigente a regra do artigo 310 do Código de Processo Penal, no sentido de se encaminhar ao Juiz os autos de prisão em flagrante em até vinte e quatro horas após a prisão, a fim de que seja deliberado sobre a legalidade do ato, ratificando a medida constritiva ou concedendo liberdade provisória/relaxamento de prisão.

Constata-se que o direito previsto na norma convencional já incorporada ao sistema jurídico interno não era observada, sendo tal medida imprescindível para coibir possíveis abusos de autoridade de agentes públicos, para diminuir a superlotação carcerária, além de 
possibilitar a ampla defesa e o contraditório por ocasião da decisão sobre a legalidade/necessidade da prisão, nos termos do art. $5^{\circ}$, inciso LIV, da CRFB/1988 que prevê: ninguém será privado da liberdade ou de seus bens sem o devido processo legal.

Em sede de controle difuso de convencionalidade, algumas decisões judiciais ${ }^{15}$ asseguraram o direito previsto no Pacto de São José da Costa Rica fomentando ações estatais como a elaboração de um projeto de lei em trâmite no Senado Federal (PLS 554/2011), que visa à regulamentação da matéria de forma pormenorizada.

A importância do controle jurisdicional de convencionalidade das Leis e sua aplicação pelos Juízes e Tribunais impulsionaram a iniciativa do Conselho Nacional de Justiça em implementar as audiências de custódia em todo país de forma escalonada.

Por sua vez, o controle de convencionalidade no sistema interamericano de proteção de Direitos Humanos se dá por intermédio da Jurisdição contenciosa e consultiva exercida pela Corte Interamericana de Direitos Humanos, competente para julgar as questões envolvendo direitos civis e políticos previstos no Pacto de São Jose da Costa Rica.

No contexto da proteção internacional, há o mecanismo unilateral de controle que se inicia a partir de denúncias de um Estado-parte sobre condutas lesivas aos direitos humanos por parte de outro Estado. Por sua vez, os mecanismos coletivos são definidos por André de Carvalho Ramos:

\footnotetext{
Um segundo modo de controle de convencionalidade é aquele feito por mecanismos coletivos, nos quais é apurado se determinada conduta do Estado (por exemplo, a edição de lei, a prolação de uma sentença ou um ato administrativo) é compatível com as normas internacionais. Como já expus em obra anterior, 'As diferenças são claras: no mecanismo unilateral prevalece o princípio do judex in causa sua, o que é substituído, nos mecanismos coletivos, por procedimentos onde a imparcialidade e o devido processo legal imperam no processamento da responsabilidade internacional do Estado'.
}

Diante dessas considerações, seria possível que atos do Poder Legislativo, Executivo ou Judiciário fossem questionados pelo cidadão ou por entidades representativas perante o sistema interamericano de Direitos Humanos?

A resposta é afirmativa ao levar-se em consideração as obrigações assumidas pelo Estado Brasileiro na Convenção Americana de Direitos Humanos e sua submissão ao sistema jurídico interamericano. Nesse sentido adverte Valério Mazzuoli:

${ }^{15}$ HABEAS CORPUS No 1.358.323-2 TJPR; HC 0001605-61.2015.4.02.0000 TRF 2 2a Região. 


\begin{abstract}
O Poder Judiciário, por sua vez, não obstante ser independente e ter garantida a sua atuação jurisdicional, também pratica ilícito internacional, afetando o Estado em matéria de responsabilidade internacional. Para o direito das gentes, os atos do Poder Judiciário são, em última análise, atos estatais e como tais devem ser compreendidos. Tal ocorre, por exemplo, quando a justiça de um país julga em desacordo com tratado internacional ratificado pelo Estado e em vigor internacional, ou mesmo quando não julga com base em tratado internacional que deveria conhecer, denegando o direito da parte que o invoca com base em convenções internacionais.
\end{abstract}

Desse modo, verifica-se a possibilidade de o Sistema Interamericano de Direitos Humanos se pronunciar sobre qualquer afronta à Convenção Americana pelos Estados,

Cite-se, pela importância da temática de direitos humanos, o reconhecimento, pelo Brasil, da jurisdição obrigatória da Corte Interamericana de Direitos Humanos em 1998. De fato, exemplo marcante do controle de convencionalidade efetuado por mecanismo coletivo, afetando o Brasil, é aquele feito pela Corte Interamericana de Direitos Humanos, quer na sua jurisdição contenciosa, quer na sua jurisdição consultiva. Desde o final de 1998, aceitou-se que um órgão internacional, a Corte Interamericana, passe a ser o intérprete definitivo de direitos constantes da Convenção Americana de Direitos Humanos"

Além disso, o controle de convencionalidade configura-se um dever institucional no Estado Democrático de Direito, vinculando o exercício dos Poderes do Estado em sua atividade judicial, legislativa e Executiva.

\title{
3 A PROIBIÇÃO DO RETROCESSO EM RELAÇÃO AOS DIREITOS CIVIS E POLÍTICOS NO ÂMBITO DO ESTADO DEMOCRÁTICO DE DIREITO.
}

No Brasil, após longo período de autoritarismo, promulgou-se a Constituição da República de 1988, cujo texto afirma, no artigo primeiro, que a República Federativa do Brasil se constitui em Estado Democrático de Direito, estabelecendo como fundamentos a cidadania, a dignidade da pessoa humana, o pluralismo político e a prevalência dos Direitos Humanos, inaugurando uma nova era de democracia e participação popular.

Neste contexto, o modelo do Estado Democrático de Direito configurou-se uma

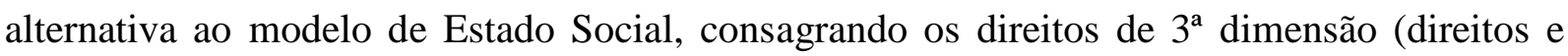
interesses difusos e coletivos), além de oferecer uma releitura constitucional dos direitos consagrados pelos modelos de Estado anteriores (Estado Liberal e Estado Social).

Sendo assim, os direitos civis e políticos são retomados como direitos de participação no debate político, fortalecendo a democracia numa sociedade pluralista e aberta, ampliando a cidadania (CARVALHO NETO, 1999). 
Para Alexy, princípios são mandamentos de otimização, “que ordenam que algo seja realizado na maior medida possível dentro das possibilidades jurídicas e fáticas existentes" (ALEXY, 2011), podendo ser satisfeitos em graus variados.

Desse modo, os princípios são concebidos como normas delimitadoras de outras normas, destacando-se o princípio da Supremacia da Constituição, da soberania, da cidadania, da dignidade da pessoa humana.

Nesta estrutura jurídica, o princípio da vedação do retrocesso leva em conta a primazia da norma mais favorável ao indivíduo/sociedade, impedindo que novas interpretações sobre as normas de direitos humanos tendem a diminuir a proteção já alcançada, ressalvadas as restrições constitucionalmente previstas.

Apesar de não constar expressamente na Constituição da República, a vedação do retrocesso ou progressividade tem fundamento nos princípios e no regime jurídico adotado pela Carta Magna, decorrendo do princípio do Estado Democrático de Direito.

Com razão Gregório Assagra ao afirmar que "qualquer reforma no sistema pátrio ou decisão judicial tem que levar em conta a proibição do retrocesso como princípio constitucional fundamental. O princípio em questão é um dos desmembramentos do princípio democrático em seu caráter dinâmico, transformador e progressista” (ALMEIDA, 2008).

Fora previsto implicitamente em vários dispositivos do protocolo de São Salvador, que trata do Pacto Internacional de Direitos Sociais, Econômicos e Culturais da Convenção Americana de Direitos Humanos, referindo-se à obrigação por parte dos Estados na adoção de medidas legislativas ou de qualquer outra natureza que fossem necessárias para tornar efetivos esses direitos.

Embora não se pretenda analisar em profundidade suas origens, que remontam a jurisprudência europeía ${ }^{16}$, foi desenvolvido primeiramente nas lutas históricas de classe como um postulado de índole social, sendo necessária uma releitura à luz das conquistas do Estado Democrático de Direito no presente século.

A importância do princípio da vedação do retrocesso aplicado aos direitos civis e políticos se fez presente no controle de convencionalidade exercido pela Corte Interamericana e pelo Supremo Tribunal Federal, em pelo menos duas oportunidades.

Antes disso, é importante observar que as interpretações da Corte Interamericana sobre os dispositivos da Convenção devem ser levadas em consideração inclusive para se exercer o

\footnotetext{
${ }^{16}$ POMPEU, Gina Vidal Marcílio. O princípio da vedação do retrocesso social diante da crise conômica do século XXI. Direito e Desenvolvimento, João Pessoa, v. 6, n. 12, p. 223.
} 
controle jurisdicional de convencionalidade das leis no âmbito interno de cada Estado. Nesta esteira, afirma Valério de Oliveira Mazzuoli:

\begin{abstract}
É importante desde já esclarecer que, no Continente Americano, a obrigação de controlar a convencionalidade das leis remonta à entrada em vigor da Convenção Americana (em 18 de julho de 1978, nos termos do seu art. 74,2). Ocorre que mais de vinte anos depois é que foi o termo "controle de convencionalidade" efetivamente aparecer, especialmente nas sentenças da Corte Interamericana. Esta (desde 2006) tem entendido devam os juízes e tribunais internos proceder ao exame da compatibilidade das leis com a Convenção Americana, levando em conta não somente a Convenção, mas também a interpretação que dela faz a Corte Interamericana, intérprete última e mais autorizada do Pacto de San José.
\end{abstract}

Por outro lado, as opiniões consultivas emanadas pela Corte Interamericana tem se consolidado como importante fonte de pareceres em matéria de Direitos Humanos, sendo de rigor sua observação pelos Estados-partes.

Nesse compasso, cabe destacar o voto em separado do Juiz Rodolfo Piza na opinião consultiva 04/84 da CIDH, na qual defende que o princípio da proibição do retrocesso em Direitos humanos deve ser aplicado também aos direitos civis e políticos, nestes termos:

Por otra parte, la alusión al artículo 26 de la Convención se deriva de mi convicción de que la distinción entre derechos civiles y políticos y derechos económicos, sociales y culturales, obedece meramente a razones históricas y no a diferencias de naturaleza jurídica de unos y otros; de manera que, en realidad, lo que importa es distinguir, con un criterio técnico jurídico, entre derechos subjetivos plenamente exigibles, valga decir, "exigibles directamente por sí mismos", y derechos de carácter progresivo, que de hecho se comportan más bien como derechos reflejos o intereses legítimos, es decir, 'exigibles indirectamente', a través de exigencias positivas de carácter político o de presión, por un lado, y de acciones jurídicas de impugnación de lo que se les oponga o de lo que los otorgue com discriminación.

Naquela oportunidade, o magistrado reconheceu que a divisão entre direitos civis e políticos de um lado, e direitos econômicos, sociais e culturais de outro, é meramente histórica e circunstancial e não condiz com o sistema de proteção conferido pela Convenção Americana de Direitos Humanos.

De outro modo, o Supremo Tribunal Federal na ADIN 4578, de relatoria do Ministro Luiz Fux, discutiu-se sobre o princípio da proibição do retrocesso em relação ao dispositivo contido no Projeto de Lei "da ficha limpa", que tornava inelegível o cidadão que fosse condenado por órgão colegiado em decisão pendente de recurso frente ao princípio da presunção de inocência. 
Extrai-se do referido acórdão que ocorrerá a incidência da vedação do retrocesso se presente o pressuposto básico consistente em, "anteriormente, a exegese da própria norma constitucional se tenha expandido, de modo a que essa compreensão mais ampla tenha alcançado consenso básico profundo e, dessa forma, tenha radicado na consciência jurídica geral" (BRASIL, 2010).

Outro aspecto relevante é a verificação de arbitrariedade na restrição legislativa, não amparada pela Constituição da República, que do mesmo modo afastará a norma inconstitucional pela infringência ao aludido princípio.

Desse modo, não é possível estabelecer a categorização dos Direitos Humanos a fim de afastar a incidência da vedação do retrocesso, uma vez que a proteção jurídica estabelecida pela Constituição da República é ampla e não prevê tal restrição.

A indivisibilidade dos Direitos Humanos é característica nuclear no âmbito da Teoria dos Direitos Fundamentais e como tal deve ser reconhecida para afastar a segmentação da proteção conferida a esses mesmos direitos.

\section{CONCLUSÃO}

O Supremo Tribunal Federal adotou a tese da supralegalidade em relação aos Tratados de Direitos Humanos, considerando-os hierarquicamente abaixo da Constituição Federal e acima das leis ordinárias. No entanto, vários juristas brasileiros defendem que tais tratados devam ser considerados normas constitucionais, independentemente se aprovados ou não com o quórum qualificado exigido para as emendas constitucionais.

O desenvolvimento da teoria do controle jurisdicional de convencionalidade das Leis e o seu reconhecimento pelos Juízes e Tribunais do país tem contribuído para a efetivação dos Tratados de Direitos humanos, tornando inválidas leis que contrariem seus dispositivos.

Além da proteção interna por meio do controle difuso de convencionalidade, destacouse que o sistema interamericano de proteção dos Direitos Humanos conta com instrumentos de acesso à justiça em caso de descumprimento de Tratados de Direitos Humanos.

O Brasil se submeteu à jurisdição prevista na Convenção Americana de Direitos Humanos desde 1998, e os atos estatais, sejam oriundos do Poder Executivo, Legislativo ou Judiciário, que infrinjam suas disposições, podem ser submetidos ao controle de convencionalidade exercido pela Corte Interamericana. 
O princípio da proibição do retrocesso e a possibilidade de sua aplicação aos direitos civis e políticos, posição já defendida em voto separado na opinião consultiva 04/84 da CIDH, tem respaldo na jurisprudência do Supremo Tribunal Federal, quando houver restrição indevida ao direito fundamental não prevista na Constituição, ou diante de novo entendimento jurisprudencial que viole interpretação uniforme e de amplo consenso, já incutida na consciência jurídica geral.

Os Direitos Humanos têm como característica importante a indivisibilidade, sendo a divisão entre direitos civis e políticos de um lado, e direitos econômicos, sociais e culturais de outro, meramente histórica e circunstancial. Sendo assim, direitos civis e políticos em muitos casos exigirão prestações positivas por parte do Estado, e por outro lado, direitos sociais poderão admitir, para sua máxima efetivação, uma abstenção estatal.

O princípio da vedação do retrocesso deriva do próprio Estado Democrático de Direito e uma vez ocorrendo uma lesão ou ameaça de lesão aos direitos fundamentais previstos na Constituição da República ou em Tratados de Direitos humanos, o controle de convencionalidade é instrumento adequado para garantia dos direitos e para a reparação do dano causado.

\section{REFERÊNCIAS}

ALEXY, Robert. Teoria dos Direitos Fundamentais. Tradução Virgilio Afonso da Silva. São Paulo: Malheiros Editores. $2^{\mathrm{a}}$ ed. $4^{\mathrm{a}}$ tiragem, 2011.

ALMEIDA, Gregório Assagra de. Direito material coletivo: superação da summa divisio direito público e direito privado por uma nova summa divisio constitucionalizada.

ALMEIDA, Gregório Assagra de. Direitos fundamentais e sua proteção nos planos Interno e Internacional / Aziz Tuffi Saliba, Luiz Manoel Gomes Júnior e Gregório Assagra de Almeida; Belo Horizonte: Arraes Editores.

BRASIL. Constituição (1988). Constituição da República Federativa do Brasil. Disponível em:<http:www.senado.gov.br/sicon>. Acesso em: 01.04.2016.

BRASIL. Supremo Tribunal Federal. Disponível em: $\langle$ http:www.stf.jus.br/>. Acesso em: 01.04.2016.

BRASIL. Decreto no 592, de 6 de julho de 1992. Disponível em:<http:www.planalto.gov.br/>. Acesso em: 01.04.2016. 
CANÇADO TRINDADE, Antônio Augusto. Tratado de Direito Internacional dos Direitos Humanos, volume II, Porto Alegre, Sérgio Antônio Fabris Editor, 1999.

CAPPELlETTI, Mauro. Acesso à justiça. Tradução de Ellen Gracie Northfleet. Porto Alegre, Fabris, 1988.

CARVALHO NETO, Menelick de. O requisito essencial da imparcialidade para a decisão constitucionalmente adequada de um caso concreto no paradigma constitucional do Estado Democrático de Direito. Revista de Direito Público, Belo Horizonte, v. 1, n. 1, jan/jun 1999.

COUTO CORREIA, Theresa Rachel. Corte Interamericana de Direitos Humanos Repercussão Jurídica das Opiniões Consultivas. Juruá Editora, 2008.

MAZZUOLI, Valério de Oliveira. Curso de direito internacional público. 5. ed. rev., atual. e ampl. -São Paulo: Editora Revista dos Tribunais, 2011.

MAZZUOLI, Valério de Oliveira $\mathbf{O}$ controle jurisdicional da convencionalidade das leis / Valerio de Oliveira Mazzuoli; prefácio Luiz Flávio Gomes. - 2. ed. rev., atual. e ampl. - São Paulo : Editora Revista dos Tribunais, 2011. - (Coleção direito e ciências afins ; v. 4 / coordenação Alice Bianchini, Luiz Flávio Gomes, William Terra de Oliveira).

MENDES, Gilmar Ferreira. Curso de Direito Constitucional / Gilmar Ferreira Mendes, Inocêncio Mártires Coelho, Paulo Gustavo Gonet Branco. 2 ed. rev. e atual. São Paulo: Saraiva, 2008.

PIOVESAN, Flávia. Direitos Humanos e o direito constitucional internacional. 12 ed.rev. atual.São Paulo: Saraiva, 2011.

POMPEU, Gina Vidal Marcílio. O princípio da vedação do retrocesso social diante da crise conômica do século XXI. Direito e Desenvolvimento, João Pessoa, v. 6, n. 12, p. 223.

RAMOS, André de Carvalho. Tratados Internacionais: Novos espaços de atuação do Ministério Público. B. Cient. ESMPU, Brasília, a. II - nº 7, p. 81-100 - abr./jun. 2003.

RIBEIRO, Jomara de Carvalho. A responsabilidade do Estado perante a Corte Internacional de Justiça. Porto Alegre: Sérgio Antônio Fabris. Ed. 2012.

TOMAZ, Carlos Alberto Simões de. Direito, Razão e Sensibilidade (construindo um modelo de juiz para a proteção dos direitos fundamentais). Pará de Minas, MG: Virtual books Editora, 2014. 